\title{
Repercussions of low fructose-drinking water in male rats
}

\author{
CAROLINA A. MIRANDA ${ }^{1}$, TATIELE E. SCHÖNHOLZER ${ }^{1}$, EDUARDO KLÖPPEL ${ }^{1}$, YURI K. \\ SINZATO $^{2}$, GUSTAVO T. VOLPATO ${ }^{1,2}$, DÉBORA C. DAMASCENO ${ }^{2}$ and KLEBER E. CAMPOS ${ }^{1}$ \\ ${ }^{1}$ Laboratório de Fisiologia de Sistemas e Toxicologia Reprodutiva, Instituto de Ciências Biológicas e da Saúde, \\ Universidade Federal de Mato Grosso/UFMT, Avenida Valdon Varjão, 6390, 78600-000 Barra do Garças, MT, Brazil \\ ${ }^{2}$ Laboratório de Pesquisa Experimental de Ginecologia e Obstetrícia, Faculdade de Medicina de Botucatu, \\ Universidade Estadual Paulista/UNESP, Distrito de Rubião Junior, s/n, 18618-970 Botucatu, SP, Brazil
}

Manuscript received on September 6, 2017; accepted for publication on July 9, 2018

\begin{abstract}
How to cite: MIRANDA CA, SCHÖNHOLZER TE, KLÖPPEL E, SINZATO YK, VOLPATO GT, DAMASCENO DC AND CAMPOS KE. 2019. Repercussions of low fructose-drinking water in male rats. An Acad Bras Cienc 91: e20170705. DOI 10.1590/0001-3765201920170705.
\end{abstract}

\begin{abstract}
Fructose consumption has increased worldwide, and it has been associated with the development of metabolic diseases such as insulin resistance (IR) and steatosis. The aim was to evaluate if lower fructose concentrations may cause pancreatic structural abnormalities, leading to a glucose intolerance without steatosis in male rats. Young male rats orally received 7\% fructose solution for 12 weeks. Body weight, food, water, and energy intake were measured. An oral glucose tolerance test (OGTT) was performed. After final experimental period, all rats were anaesthetized and killed. Blood samples were collected for biochemical analyses and organs (liver and pancreas) were processed for morphological analyses. Fructose consumption was not associated with lipid accumulation in liver. However, fructose administration was associated with an increased area under curve from OGTT and an increased percentage of insulin-positive cells, high beta cell mass and reduced pancreatic islet area. Fructose supplementation (7\%) did not cause steatosis, but it led to abnormal morphology and function of pancreatic islet cells, contributing for glucose intolerance development. Our findings demonstrate that even low fructose concentrations may cause deleterious effects in animals.
\end{abstract}

Key words: fructose, glucose intolerance, islet pancreatic, steatosis.

\section{INTRODUCTION}

Most of available animal models of glucose intolerance are based on rodents. In animal models, deficiency in insulin production can occur either spontaneously or be induced by chemicals or dietary or surgical manipulations and/or by a combination. One disadvantage with chemically inducing

Correspondence to: Carolina Abreu Miranda

E-mail: carol.fisiotox@hotmail.com

ORCid: https://orcid.org/0000-0002-4402-1466 glucose intolerance or insulin resistance (IR) is that chemicals can be toxic to other organs. Some studies have shown that high fructose consumption can alter metabolic events, both in human and experimental models, contributing to development of disorders such as hypertriglyceridemia, obesity, and high blood pressure. In addition, it can lead to hyperinsulinemia and IR, which characterize metabolic syndrome (Basciano et al. 2005, Evans et al. 2017, Tran et al. 2009). 
Fructose is a natural, simple sugar found in fruits and honey that is responsible for their sweet taste. However, most fructose consumed worldwide is derived from sucrose, or table sugar, which is obtained from sugar cane and sugar beets. Sucrose is a disaccharide that consists of $50 \%$ fructose and $50 \%$ glucose. After ingestion, sucrose is degraded in the gut by sucrase, which releases free fructose and glucose for absorption. In addition to sucrose, other major source of fructose is high fructose corn syrup (HFCS), which was first introduced to food and beverage industry in early 1970 s as an additional sweetener (Johnson et al. 2009).

Fructose at different concentrations in food (30-67\%) (Crescenzo et al. 2014, Karsenty et al. 2013, Zaman et al. 2011) or water (10-25\%) (Abdulla et al. 2011, Roglans et al. 2007, Wong et al. 2015) has been used to induce metabolic disorders in experimental models. However, in addition to IR and hyperglycemia, fructose in drinking water has been shown to cause steatosis (Alwash et al. 2014, El-Haleim et al. 2016, Ishimoto et al. 2012). Herein the objective was to evaluate if lower fructose concentrations may lead to pancreatic structural abnormalities, leading to a glucose intolerance without steatosis in male rats.

\section{MATERIALS AND METHODS}

ANIMALS

Male Wistar rats (35-days-old) were obtained in Vivarium and were maintained in Laboratory of Physiology of Systems and Reproductive Toxicology (FISIOTOX). Animals were housed two or three per cage and kept under standard conditions $\left(22 \pm 3{ }^{\circ} \mathrm{C}, 12 \mathrm{~h}\right.$ light/dark cycle), received standard rat chow diet (Purina rat chow, Purina ${ }^{\circledR}$, São Paulo, SP, Brazil) and were given tap water to drink $a d$ libitum during acclimation period of seven days. The Ethical Committee for Animal Research of UFMT, Brazil, approved protocols used in this study (Protocol number 23108.705702/13-9).

\section{EXPERIMENTAL GROUPS}

The rats (42-days-old) were randomly distributed into two dietary-based experimental groups: 1) Control group $(n=6)$ : rats drinking water, and 2) Fructose group $(n=5)$ : rats drinking $7 \%(w / v)$ fructose solution. Both experimental groups had ad libitum access to food and drinking liquid for 12 weeks (or 3 months). Body weight, food and water intake was monthly measured. Furthermore, energy intake was also evaluated in food and water consumption (Diniz et al. 2005).

\section{ORAL GLUCOSE TOLERANCE TEST (OGTT)}

After 11 weeks of experiment, all animals were submitted to an oral glucose tolerance test (OGTT). For this, animals were fasted for 12 hours, and glucose levels were determined in a blood drop collected from the rats by tail vein puncture (timepoint 0). Subsequently, a glucose solution $(2.0 \mathrm{~g} / \mathrm{kg} \mathrm{BW})$ was administered by intragastric route (gavage), and blood glucose were similarly measured at 30,60 and 120 minutes after glucose overload (Santos et al. 2015) using a conventional glucometer (One Touch Ultra Johnson \& Johnson ${ }^{\circledR}$ ). Glucose responses during OGTT were evaluated by estimation of total area under curve (AUC), using trapezoidal method (Tai et al. 1994).

\section{BIOCHEMICAL PARAMETERS AND ORGAN COLLECTING}

After a 12-week experimental period, and after overnight fasting (12 hours), all rats were anesthetized with sodium thiopental (Thiopentax ${ }^{\circledR}$, São Paulo, Brazil) and killed by decapitation. Blood samples were collected and glycaemia determinations were performed using a conventional glucometer. The remaining blood was placed into anticoagulant-free test tubes, maintained at a low temperature for $30 \mathrm{~min}$ and then centrifuged at $1,300 \times \mathrm{g}$ for 10 minutes at 4 ${ }^{\circ} \mathrm{C}$. The supernatant was collected as serum and 
stored at $-80{ }^{\circ} \mathrm{C}$ for further determination of total cholesterol, triglycerides, high-density lipoprotein (HDL), alanine aminotransferase (ALT) and aspartate aminotransferase (AST) by enzymatic determination using Wiener ${ }^{\circledR}$ assay kits (Rosario, Argentina). Serum very-low-density lipoprotein (VLDL) was estimated by calculation of previously measured lipid concentrations (cholesterol, triglycerides and HDL levels) (Friedewald et al. 1972). Insulin determination was performed using an ELISA kit (Protocol number: 90060; Crystal Chemical $^{\circledR}$, USA). Moreover, liver, pancreas and periepididymal fat were individually collected and weighed for relative weight determination.

STRUCTURAL AND IMMUNOHISTOCHEMICAL ANALYSES

A portion of liver and pancreas was placed in neutral buffered formalin $(10 \%$ formalin in phosphate buffer) for $24 \mathrm{~h}$ and then placed in $70 \%$ ethanol. Fragments were processed, embedded in paraffin, and later sectioned using a microtome $(5 \mu \mathrm{m})$.

Liver was stained with haematoxylin-eosin (HE). Morphometric analysis was performed using an imaging computer system (KS-300 software, 3.0 version, Zeiss $\left.{ }^{\circledR}\right)$, which receives an image through a digital camera (CCD-IRIS/RGB Sony ${ }^{\circledR}$ ) and is coupled to a microscope (DMR, Leica ${ }^{\circledR}$ ).

Pancreatic samples were used for immunohistochemical analysis. Sections were rinsed and rehydrated through a graded ethanol series. Primary antibody was anti-insulin [Mouse monoclonal (D6C4) to insulin, Abcam; AB8304]. Immunohistochemical procedure included following steps: (1) tissue antigen retrieval with citrate solution ( $\mathrm{pH}$ 6.0) in a Pascal pressure cooker (Dako); (2) blocking of endogenous peroxidase using a ready-for-use hydrogen peroxide solution (Spring; DHP-125); (3) blocking nonspecific proteins with Protein Block (Dako); (4) incubation with primary antibody at a dilution of 1:10,000 for two hours; (5) incubation with secondary antibody
Histofine (Simple Stain Max Po. Universal Immuno-Peroxidase Polymer/Anti-Mouse) for $30 \mathrm{~min}$ at $27{ }^{\circ} \mathrm{C}$; (6) peroxidase revelation using chromogen DAB (3,3'-diaminobenzidine); (7) and counter-staining with Mayer's haematoxylin.

Morphometric analysis of insulin-positive paraffin sections was performed to determination total area of pancreatic islet using software QWIN, 3.7.1 version, Leica ${ }^{\circledR}$ and measure beta cell mass. Cell masses were calculated by multiplying volume of pancreatic beta cell with corresponding pancreatic weight. Volume of pancreatic beta cell was calculated by dividing insulin-positive cell by number of nuclei in that islet (Song et al. 2015).

$$
\text { Cell mass }=\text { Volume } \mathrm{x} \text { Pancreas Weight }
$$

$$
\text { Volume }=\frac{\text { Insulin-Positive Cells }}{\text { Total Nucleus }}
$$

\section{STATISTICAL EVALUATION}

Results are presented as mean \pm standard deviation. Gamma and Binomial distribution were performed in cases where data did not present a normal distribution. For normal distribution, a Student's unpaired $t$-test to compare only two groups or one-way ANOVA followed by Tukey's Multiple Comparison test were performed to compare glycaemia at different time points in OGTT. A $\mathrm{p}<0.05$ was considered as a statistically significant difference in relation to control group.

\section{RESULTS}

The group of rats given drinking water enriched with $7 \%$ fructose presented no significant changes in their final body weights, but body weight gain was increased at experimental month 2 (Figure 1a). However, fructose group increased water consumption (Figure 1b), decreased food consumption except at month 2 of experiment (Figure 1c), and energy intake (Figure 1d). 

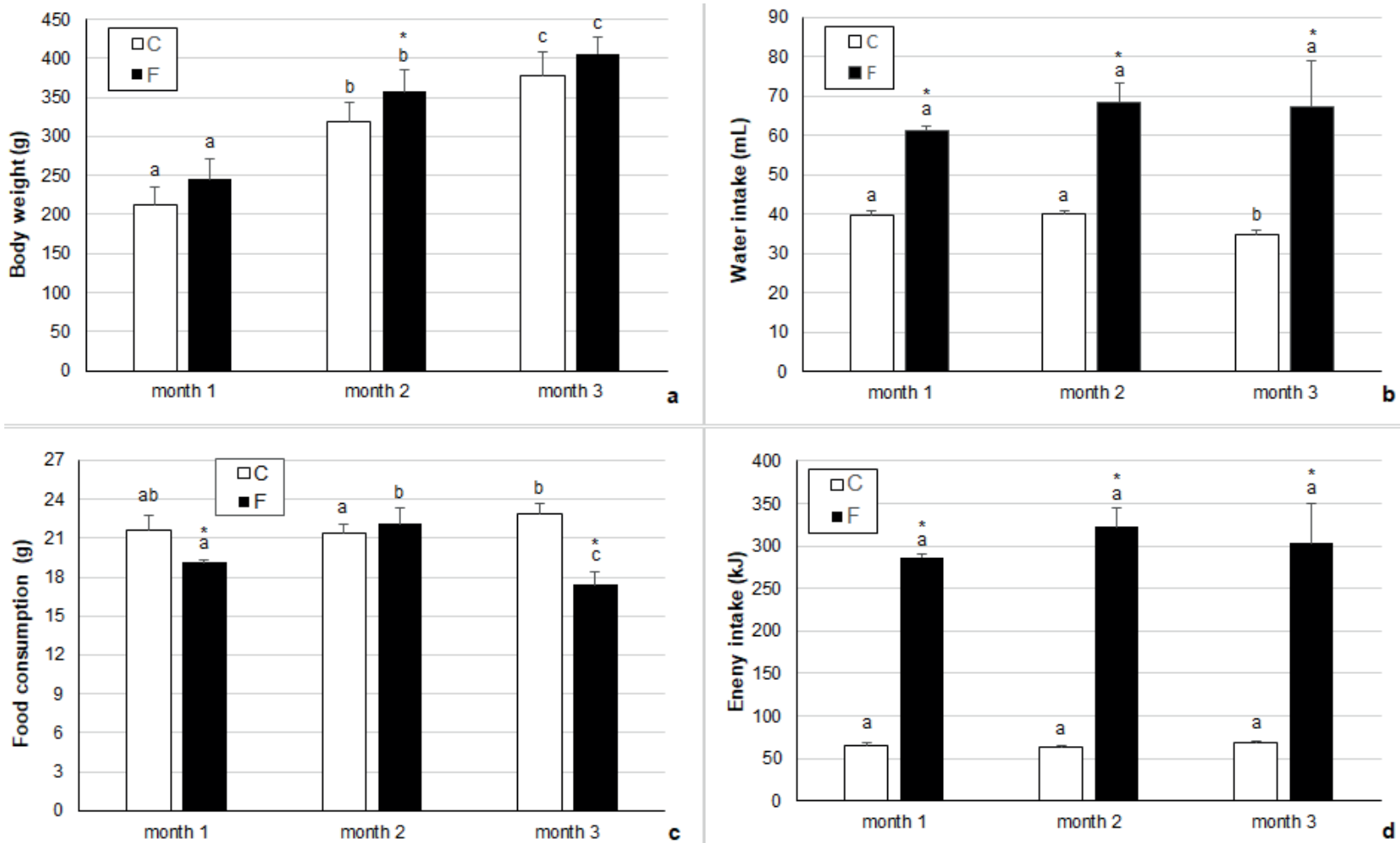

Figure 1 - Body weight (a). Water intake (b). Food consumption (c). Energy intake (d) of control and fructose groups.

Data shown as mean \pm standard deviation (SD).

Values followed by lowercase letters differ among months into same experimental group (Tukey's multiple comparison test).

${ }^{*} \mathrm{p}<0.05$ - compared with control group (Student $\mathrm{t}$ test).

At the end of experimental period, animals that received fructose supplementation showed no differences between groups in evaluation of fasting blood glucose levels and insulin levels. In addition, there were no differences in biochemical parameters evaluated (Table I) and hepatic morphological analyses (Figure 2a, b).

OGTT evaluation after glucose overload shows the fructose group presented higher blood glucose levels after 30 and 60 minutes (Figure 3a), and total AUC had also increased (Figure $3 \mathrm{~b}$ ). In addition, fructose group showed reduced area of pancreatic islet (Figure 4c) and an increased percentage of insulin positive beta cells (Figure 4d) and beta cell mass (Figure 4e).

Table II presents relative organ weights. Data revealed increased pancreatic weights only in fructose group.

\section{DISCUSSION}

In present study, we hypothesized that low fructosedrinking water $(7 \%)$ was sufficient to cause glucose tolerance with abnormalities in pancreatic histophysiology, but not steatosis. Fructose intake effects in several experimental studies using highest concentrations of this sugar are performed, which are not compatible with human consumption. In experimental models, rats tolerate a diet with high levels fructose ( $\geq 60 \%$ ), whereas humans can develop gastric distress even at lower fructose doses ( $\geq 10 \%$ ) (White et al. 2013). Therefore, we chose to administrate lower fructose concentrations to reproduce human fructose consumption and to avoid steatosis.

The results showed that fructose administration led to an increased water intake and energy intake throughout experimental period, even decreased 
TABLE I

Biochemical profile of control and fructose rats.

\begin{tabular}{ccc}
\hline & & Groups \\
\cline { 2 - 3 } & Control & Fructose \\
\hline Glucose $(\mathrm{mg} / \mathrm{dL})$ & $85.9 \pm 11.7$ & $70.5 \pm 14.2$ \\
Insulin $(\mathrm{ng} / \mathrm{mL})$ & $0.3 \pm 0.2$ & $0.4 \pm 0.2$ \\
ALT (U/L) & $36.6 \pm 9.4$ & $42.9 \pm 3.6$ \\
AST (U/L) & $168.2 \pm 19.5$ & $186.1 \pm 30.8$ \\
CHO (mg/dL) & $73.4 \pm 6.8$ & $77.0 \pm 12.3$ \\
TG (mg/dL) & $88.2 \pm 28.5$ & $95.5 \pm 4.7$ \\
HDL-c (mg/dL) & $42.0 \pm 5.7$ & $44.2 \pm 13.5$ \\
VLDL-c (mg/dL) & $18.2 \pm 7.3$ & $19.1 \pm 0.9$ \\
\hline
\end{tabular}

Data shown as mean \pm standard deviation (SD).

TABLE II

Relative organ weight of control and fructose rats.

\begin{tabular}{ccc}
\hline & \multicolumn{2}{c}{ Groups } \\
\cline { 2 - 3 } & Control & Fructose \\
\hline Liver & $3.09 \pm 0.34$ & $3.38 \pm 0.09$ \\
Periepididymal fat & $0.84 \pm 0.35$ & $1.10 \pm 0.17$ \\
Pancreas & $0.16 \pm 0.02$ & $0.19 \pm 0.03^{*}$ \\
\hline
\end{tabular}

Data shown as mean \pm standard deviation (SD).

${ }^{*} \mathrm{p}<0.05-$ Student $\mathrm{t}$ test.

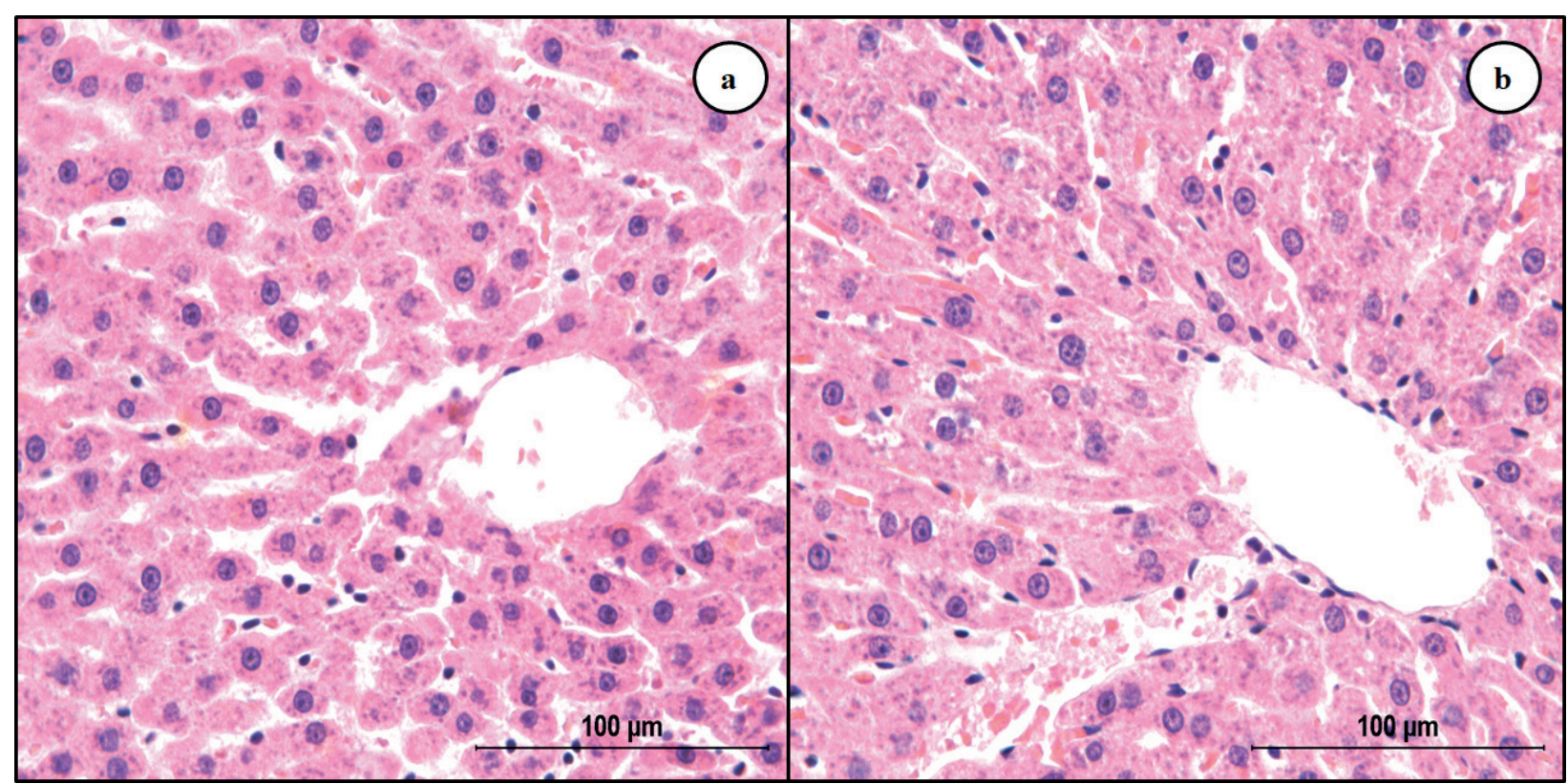

Figure 2 - Photomicrograph showing liver sections from control (a) and fructose (b) groups (H \& E stain, magnification x 400). 

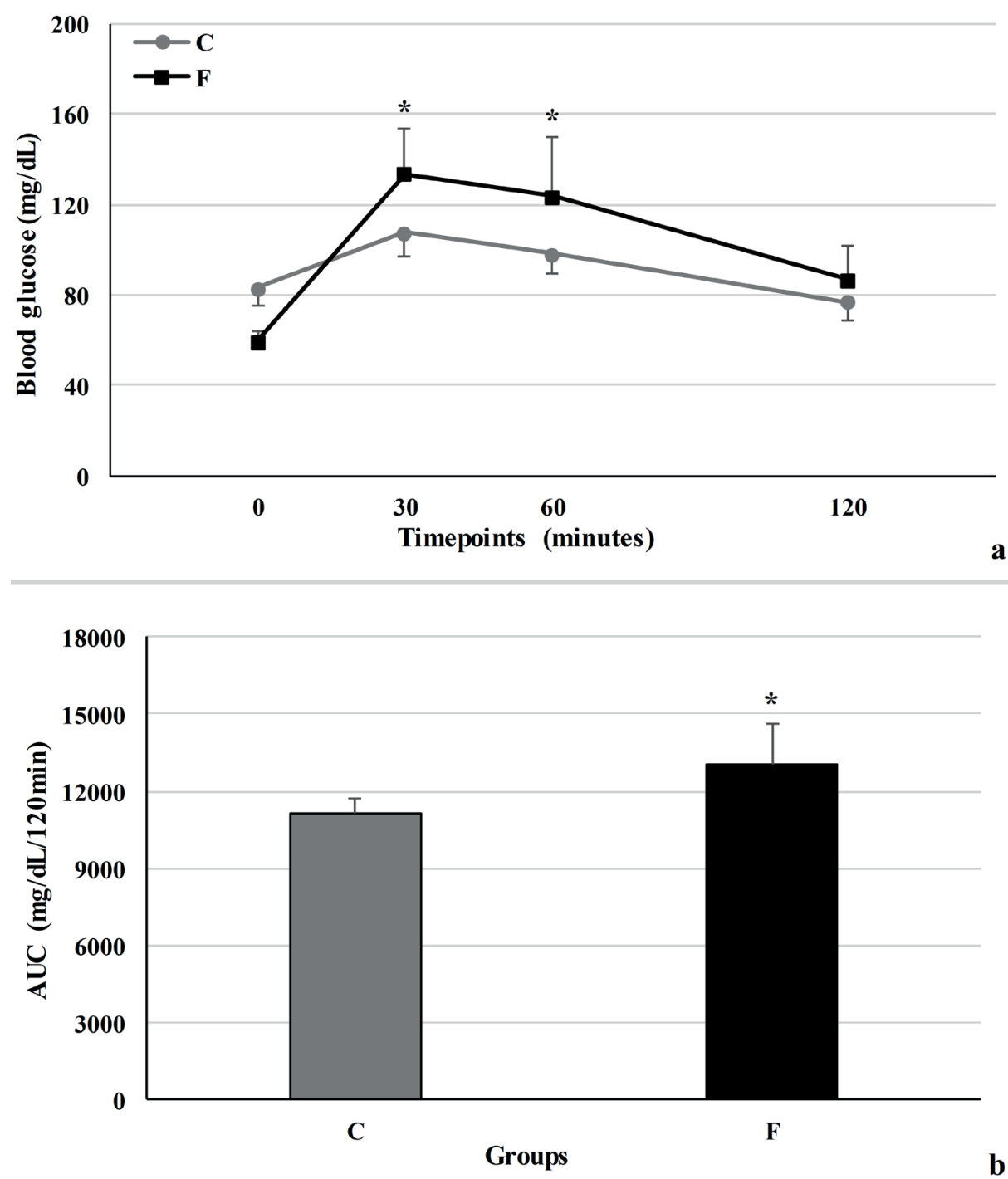

Figure 3 - Oral glucose tolerance test (OGTT) (a). Area under curve OGTT (b) of control and fructose rats.

Data shown as mean \pm standard deviation (SD).

$* \mathrm{p}<0.05$ - compared with control group (Student $\mathrm{t}$ test).

food consumption. According to previous studies, animals treated by varying concentrations of fructose also consumed more water and less food (Baena et al. 2016, Jurgens et al. 2005, Sheludiakova et al. 2012), corroborating our results. Since fructose solutions are characterized by increased energy intake and palatability (Baena et al. 2016, Ishimoto et al. 2012, Jurgens et al. 2005), it was expected that fructose supplementation would be associated with higher body weight of animals. However, both groups presented gradual increase of body weight during experimental period. Further, increased energy intake in fructose group was observed, which can be explained by increased fructosedrinking water consumption. The impact of fructose consumption on body weight and fat gain continues to be controversial; and some studies have stated that body weight gain is associated with fructose consumption (El-Haleim et al. 2016, Horvath et al. 2001, Wu et al. 2015), while others observe no 

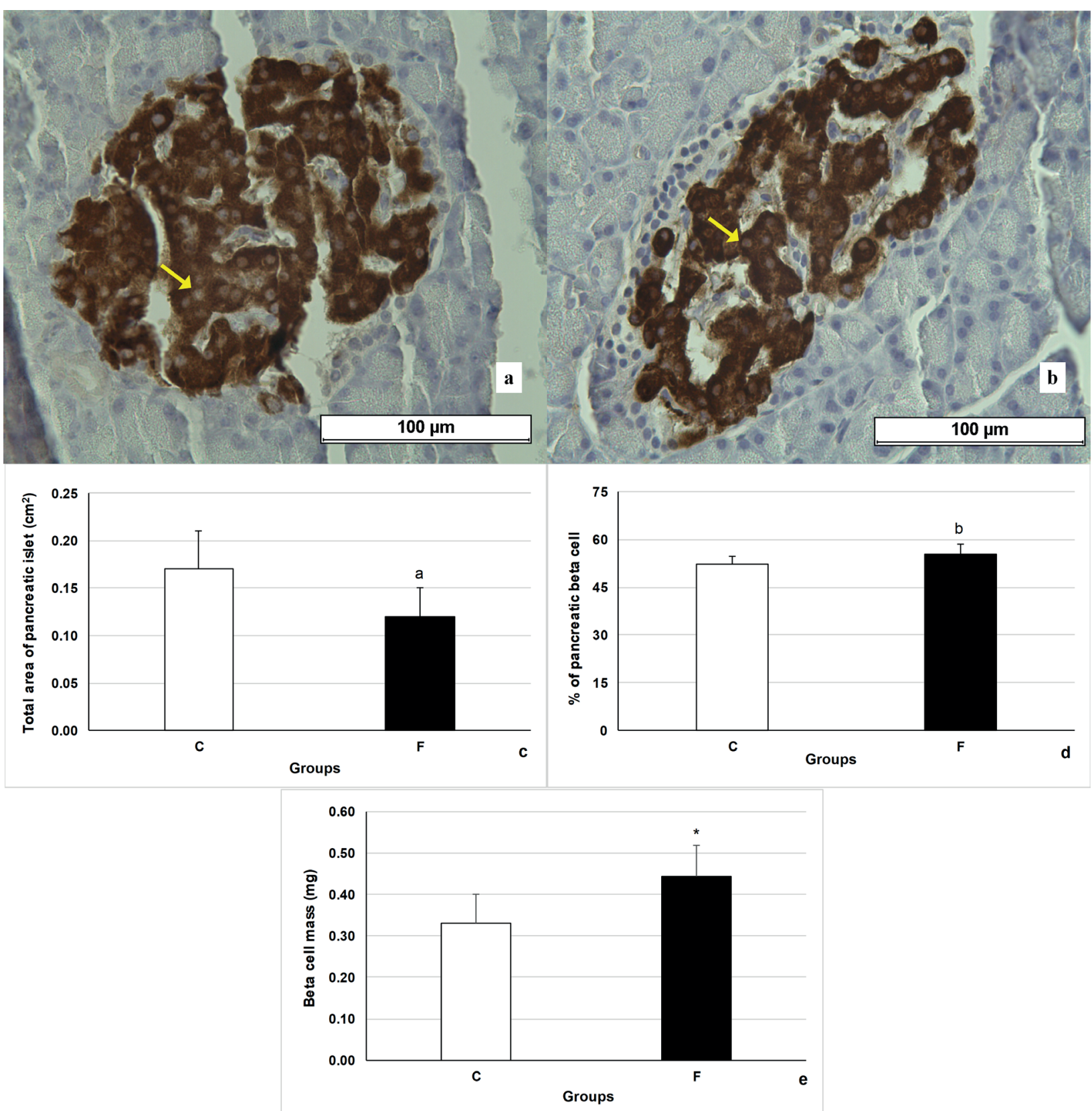

Figure 4 - Photomicrographs of insulin immunohistochemical staining of pancreatic islets. Section of the pancreas of the control group (a) showing strong immunoreactivity of insulin in beta cells (arrow), which occupy most of the islet. Pancreas of fructose group (b) showing marked reduction in the islet area and increased number of insulin-stained beta cells (IHC by anti-insulin antibodies, magnification x 400). Total area of pancreatic islet (c) from control and fructose groups. Percentage of pancreatic beta cells (d). Beta cell mass (e) stained with insulin from control and fructose groups.

Data shown as mean \pm standard deviation (SD).

${ }^{\mathrm{a}} \mathrm{p}<0.05$ - Gamma Distribution.

${ }^{\mathrm{b}} \mathrm{p}<0.05$ - Binomial Distribution.

$* \mathrm{p}<0.05-$ Student $\mathrm{t}$ test. 
significant impact on this parameter (Zakula et al. 2011, Araújo et al. 2016), confirming our results and could be related with low fructose dose.

Although animals given fructose solution presented increased energy intake, no changes were observed in total cholesterol and triglyceride levels. These findings corroborate with other published results of research involving animals (Elliot et al. 2002, Ishimoto et al. 2012, Zaman et al. 2011) and humans (Elliot et al. 2002, Stanhope et al. 2008, Sun et al. 2011, Swarbrick et al. 2008). However, other studies show that concentrations of 10 to $25 \%$ fructose caused abnormal lipid metabolism evidenced by hypertriglyceridemia and steatosis (Alwash et al. 2014, El-Haleim et al. 2016, Jurgens et al. 2005, Sadi et al. 2015).

Fructose consumption in concentrations of 10\% (El-Haleim et al. 2016), 15\% (Ishimoto et al. 2012, Jurgens et al. 2005), 20\% (Sadi et al. 2015) and 30\% (Alwash et al. 2014, Ishimoto et al. 2012) leads to hepatic steatosis because fructose contributes for an increased de novo lipogenesis in liver (Mayes 1993, Tappy et al. 2010), leading to a lipid accumulation in hepatocytes. However, in our study consumption of fructose $(7 \%)$ did not alter lipid profile in blood of treated rats and thus steatosis was not observed.

Our results showed glycemic changes after glucose load during OGTT and increased AUC of fructose group, confirming glucose intolerance. A possible mechanism to explain this finding might be from impaired beta-cell function. Even low fructose consumption was associated with morphologically abnormal pancreatic islets with a reduced pancreatic islet area, increased total number of cells insulin positive and beta cell mass, but with unaltered serum insulin concentrations. Reductions in islet areas have been observed after fructose administration at a concentration of $10 \%$, which could be indicative of primary defects in pancreatic beta cell function (Maiztegui et al. 2009, Pokrywczynska et al. 2014). Reduced pancreatic islet area is considered a progressive change and might be involved in type 2 Diabetes mellitus pathogenesis (Maiztegui et al. 2009, Butler et al. 2003). In order to compensate loss of beta cells, an expansion of mass of these cells was found, which could be related to proliferation/regeneration of new cells after fructose supplementation (BonnerWeir and Aguayo-Mazzucato 2016, Cerf 2013, Song et al. 2015). Furthermore, animals treated with $7 \%$ fructose showed no changes in serum fasting insulin. Fructose is unable to stimulate insulin secretion for itself, which differs from glucose effects (Capito et al. 1984, Curry 1989, Elliot et al. 2002). Therefore, considering only unchanged fasting blood glucose concentrations and serum fasting insulin levels, it suggests 7\% fructose administration does not impair peripheral glucose uptake in animals.

Our data suggest that chronic consumption of $7 \%$ fructose was insufficient to induce steatosis or cause abnormalities in fasting blood glucose and serum insulin levels. However, supplementation led to abnormal morphology and function of pancreatic islet cells, contributing for glucose intolerance development. Our findings demonstrate that even low fructose concentrations may cause deleterious effects in animals.

\section{ACKNOWLEDGMENTS}

The authors are thankful to Dr. Wellerson Rodrigo Scarano (Universidade Estadual Paulista - UNESP) for support with histological processing of liver and pancreas samples, to Franciance Quintanilha Gallego Souza (Universidade Estadual Paulista UNESP) for support during immunohistochemical procedures and analysis of pancreas, to Marcela Marcondes Pinto Rodrigues (Cevepat) for assistance with pathological analysis of liver samples, to Betina Beatriz Mielke, Dionys de Souza Almeida and Dener Lucas Araújo dos Santos (Universidade Federal de Mato Grosso - 
UFMT) for animal care in vivarium, and to Dr. José Eduardo Corrente (Universidade Estadual Paulista - UNESP) for assistance with statistical analyses. This study was financed in part by the Coordenação de Aperfeiçoamento de Pessoal de Nível Superior Brazil (CAPES), Finance Code 001.

\section{REFERENCES}

ABDULLA M, SATTAR M, JOHNS E, ABDULLAH N AND KHAN M. 2011. Evidence for the role of $\alpha 1 \mathrm{~A}$-adrenoceptor subtype in the control of renal hemodynamics in fructosefed Sprague-Dawley rat. Eur J Nutr 50(8): 689-697.

ALWASH S, XU M, SCHULTZE F, WILTING J, MIHM S, RADDATZ D AND RAMADORI G. 2014. Combination of alcohol and fructose exacerbates metabolic imbalance in terms of hepatic damage, dyslipidemia, and insulin resistance in rats. PLoS ONE 9(8): e104220.

ARAÚJO I ET AL. 2016. Early developmental exposure to high fructose intake in rats with $\mathrm{NaCl}$ stimulation causes cardiac damage. Eur J Nutr 55(1): 83-91.

BAENA M, SANGÜESA G, DÁVALOS A, LATASA MJ, SALA-VILA A, SÁNCHEZ RM, ROGLANS N, LAGUNA JC AND ALEGRET M. 2016. Fructose, but not glucose, impairs insulin signaling in the three major insulin-sensitive tissues. Sci Rep 6: 26149.

BASCIANO H, FEDERICO L AND ADELI K. 2005. Fructose, insulin resistance, and metabolic dyslipidemia. Nutr Metab 2(1): 5.

BONNER-WEIR S AND AGUAYO-MAZZUCATO C. 2016. Physiology: pancreatic $\beta$-cell heterogeneity revisited. Nature 535(7612): 365-366.

BUTLER A, JANSON J, BONNER-WEIR S, RITZEL R, RIZZA R AND BUTLER P. 2003. $\beta$-cell deficit and increased $\beta$-cell apoptosis in humans with type 2 diabetes. Diabetes 52(1): 102-110.

CAPITO K, HEDESKOV C, LANDT J AND THAMS P. 1984. Pancreatic islet metabolism and redox state during stimulation of insulin secretion with glucose and fructose. Acta Diabetol Lat 21(4): 365-374.

CERF M. 2013. Beta cell dysfunction and insulin resistance. Front Endocrinol 4: 37.

CRESCENZO R, BIANCO F, COPPOLA P, MAZZOLI A, VALIANTES S, LIVERINI G AND IOSSA S. 2014. Adipose tissue remodeling in rats exhibiting fructoseinduced obesity. Eur J Nutr 53(2): 413-419.

CURRY D. 1989. Effects of mannose and fructose on the synthesis and secretion of insulin. Pancreas 4: 2-9.

DINIZ Y, FAINE L, GALHARDI C, RODRIGUES H, EBAID G, BURNEIKO R, CICOGNAAAND NOVELLI E. 2005. Monosodium glutamate in standard and high-fiber diets: metabolic syndrome and oxidative stress in rats. Nutrition 21(6): 749-755.

EL-HALEIM E, BAHGAT A AND SALEH S. 2016. Resverastrol and fenofibrate ameliorate fructose-induced nonalcoholic steatohepatitis by modulation of genes expression. World J Gastroentero 22(10): 2931-2948.

ELLIOT S, KEIM N, STERN J, TEFF K AND HAVEL P. 2002. Fructose, weight gain, and the insulin resistance syndrome. Am J Clin Nutr 76(5): 911-922.

EVANS RA, FRESE M, ROMERO J, CUNNINGHAM JH AND MILLS KE. 2017. Chronic fructose substitution for glucose or sucrose in food or beverages has little effect on fasting blood glucose, insulin, or triglycerides: a systematic review and meta-analysis. Am J Clin Nutr 106(2): 519-529.

FRIEDEWALD W, LEVY R AND FREDRICKSON D. 1972. Estimation of the concentration of low-density lipoprotein cholesterol in plasma, without use of preparative ultracentrifugue. Clin Chem 18(6): 499-502.

HORVATH TL, DIANO S, SOTONYI P, HEIMAN M AND TSCHOP M. 2001. Minireview: ghrelin and the regulation of energy balance - a hypothalamic perspective. Endocrinol 142(10): 4163-4169.

ISHIMOTO T ET AL. 2012. Opposing effects of fructokinase $\mathrm{C}$ and $\mathrm{A}$ isoforms on fructose-induced metabolic syndrome in mice. P Natl Acad Sci USA 109(11): 4320-4325.

JOHNSON R ET AL. 2009. Hypothesis: could excessive fructose intake and uric acid cause type 2 diabetes? Endocr Rev 30(1): 96-116.

JURGENS H ET AL. 2005. Consuming fructose-sweetened beverages increases body adiposity in mice. Obes Res 13(7): 1146-1156.

KARSENTY J, LANDRIER J, ROUSSEAU-RALLIARD D, ROBBEZ-MASSON V, MARGOTAT A, DEPREZ P AND GASTALDI M. 2013. Beneficial effects of omega-3 fatty acids on the consequences of a fructose diet are not mediated by PPAR delta of PGC1 alpha. Eur J Nutr 52(8): 1865-1874.

MAIZTEGUI B, BORELLI M, RASCHIA M, DEL ZOTTO H AND GAGLIARDINO J. 2009. Islet adaptative changes to fructose-induced insulin resistance: $\beta$-cell mass, glucokinase, glucose metabolism, and insulin secretion. J Endocr 200: 139-140.

MAYES P. 1993. Intermediary metabolism of fructose. Am J Clin Nutr 58(5): S754-S765.

POKRYWCZYNSKA M, FLISINSKI M, JUNDZIL A, KRZYZANOWSKA S, BRYMORA A, DEPTULA A AND MANITIUS J. 2014. Impact of fructose diet and renal failure on the function of pancreatic islets. Pancreas 43(5): 801-808.

ROGLANS N, VILÁ L, FARRÉ M, ALEGRET M, SÁCHEZ R, VÁZQUEZ-CARRERA M AND LAGUNA J. 2007. Impairment of hepatic Stat-3 activation and reduction of 
PPAR $\alpha$ activity in fructose-fed rats. Hepatology 45(3): 778-788

SADI G, ERGIN V, YILMAZ G, PEKTAS M, YILDIRIM O, MENEYSE A AND AKAR F. 2015. High-fructose corn syrup-induced hepatic dysfunction in rats: improving effect of resveratrol. Eur J Nutr 54(6): 895-904.

SANTOS T, SINZATO Y, GALLEGO F, IESSI I, VOLPATO G, DALLAQUA B AND DAMASCENO D. 2015. Extracellular HSP70 levels in diabetic environment in rats. Cell Stress Chaperon 20(4): 595-603.

SHELUDIAKOVA A, ROONEY K AND BOAKES R. 2012. Metabolic and behavioral effects of sucrose and fructose/ glucose drinks in the rat. Eur J Nutr 51(4): 445-454.

SONG I, PATEL O, HIMPE E, MULLER CJF AND BOUWENS L. 2015. Beta cell mass restoration in alloxandiabetic mice treated with EGF and gastrin. PLoS ONE 10(10): e0140148.

STANHOPE K, GRIFFEN S, BAIR B, SWARBRICK M, KEIM N AND HAVEL P. 2008. Twenty-four-hour endocrine and metabolic profiles following consumption of high fructose corn syrup-, sucrose-, fructose-, and glucose-sweetened beverages with meals. Am J Clin Nutr 87(5): 1194-1203.

SUN SZ, ANDERSON GH, FLICKINGER BD, WILLIAMSON-HUGHES PS AND EMPIE MW. 2011. Fructose and non-fructose sugar intakes in the US population and their associations with indicators of metabolic syndrome. Food Chem Toxicol 49: 2875-2882.

SWARBRICK MM, STANHOPE KL, ELLIOTT SS, GRAHAM JL, KRAUSS RM, CHRISTIANSEN MP, GRIFFEN SC, KEIM NL AND HAVEL PJ. 2008. Consumption of fructose-sweetened beverages for 10 weeks increases postprandial triacylglycerol and
apolipoprotein-B concentrations in overweight and obese women. Br J Nutr 100: 947-952.

TAI M. 1994. A mathematical model for the determination of total area under glucose tolerance and other metabolic curves. Diabetes Care 17(2): 152-154.

TAPPY L, LE KA, TRAN CT AND PAQUOT N. 2010. Fructose and metabolic diseases: New findings, new questions. Nutrition 26: 1044-1049.

TRAN L, YUEN V AND MCNEILL J. 2009. The fructosefed rat: a review on the mechanisms of fructose-induced insulin resistance and hypertension. Mol Cell Biochem 332(1-2): 145-159.

WHITE JS. 2013. Challenging the fructose hypothesis: new perspectives on fructose consumption and metabolism. Adv Nutr 4(2): 246-256.

WONG W, WARD L, FONG C, YAP W AND BROWN L. 2015. Anti-inflammatory $\gamma$ - and $\delta$-tocotrienols improve cardiovascular, liver and metabolic function in dietinduced obese rats. Eur J Nutr 56(1): 133-150.

WU H, REN L, ZHOU X AND HAN D. 2015. A highfructose diet induces hippocampal insulin resistance and exacerbates memory deficits in male Sprague-Dawley rats. Nutr Neurosci 18(7): 323-328

ZAKULA Z, KORICANAC G, TEPAVCEVIC $\mathrm{S}$, STOJILJKOVIC M, MILOSAVLJEVIC $\mathrm{T}$ AND ISENOVIC E. 2011. Impairment of cardiac insulin signaling in fructose-fed ovariectomized female Wistar rats. Eur J Nutr 50(7): 543-551.

ZAMAN M, LERAY V, LE BLOCH J, THORIN C, OUGUERRAM K AND NGUYEN P. 2011. Lipid profile and insulin sensitivity in rats fed with high-fat or highfructose diets. Brit J Nutr 106(Suppl. 1): S206-S210. 